\title{
A Presença de Postulados Tomistas na Gênese do Serviço Social ${ }^{1}$
}

\section{The Presence of Thomist Postulates in the Origin of Social Work}

\author{
Cláudia Neves da Silva ${ }^{2}$
}

\begin{abstract}
Resumo
O presente artigo tem por objetivo estudar a presença de postulados de Santo Tomás de Aquino no surgimento do serviço social e sua repercussão na teoria e na prática profissional das primeiras profissionais da área de serviço social. Para tanto, utilizamo-nos de artigos escritos para a Revista Serviço Social, que teve grande circulação entre assistentes sociais no período de 1939 a 1952.

Palavras chave: Prática profissional, igreja católica, serviço social.
\end{abstract}

\begin{abstract}
This article highlights the presence of Saint Thomas de Aquino's postulates at the beginning of the Social Work and its influence in the theory and professional practice of the first social workers. For that matter, it is based on written articles from Revista Serviço Social, which was greatly disseminated among social workers between 1939 and 1952.
\end{abstract}

Key words: Professional practice, catholic church, social work.

O presente artigo tem por objetivo estudar a presença de postulados de Santo Tomás de Aquino no surgimento do serviço social e sua repercussão na teoria e na prática profissional das primeiras assistentes sociais. Delimitamos o período que vai de 1936 a 1945, em razão de que, após a $2^{\text {a Guerra }}$ Mundial, se fez notar uma diminuição da presença da doutrina social da Igreja Católica e, portanto, do tomismo, no conteúdo das disciplinas ministradas nos cursos de Serviço Social.

Temos observado, em alguns profissionais e alunos do curso de Serviço Social, a presença de princípios cristãos em seus discursos, tais como justiça social, amor ao próximo, caridade, boa vontade, valores recebidos em seu processo de socialização os quais não são postos de lado no cotidiano da prática profissional. Se nos reportarmos à história do surgimento do Serviço Social no Brasil, verificaremos que, não por mera coincidência, estes mesmos ideais cristãos, amplamente difundidos pela Igreja Católica, estavam presentes em sua gênese.

Foi com base nessas observações que algumas indagações surgiram: Qual a fundamentação desses ideais cristãos? Como se fizeram presentes na prática profissional e no pensamento das primeiras assistentes sociais?

A pesquisa utilizou como fontes bibliográficas, textos de filósofos e teólogos estudiosos de Santo

\footnotetext{
${ }^{1}$ Este artigo origina-se da monografia “A presença de postulados tomistas na gênese do Serviço Social”, apresentada em abril de 1995 ao Departamento de Filosofia/UEL, para obtenção do título Especialista em Filosofia.

2 Professora Assistente do Curso de Serviço Social da Universidade Estadual de Londrina. Especialização em Filosofia: História do Pensamento Brasileiro pela Universidade Estadual de Londrina; Mestre em História Social pela Universidade Estadual Paulista/Assis. Endereço: Av. Garibaldi Deliberador, no 325 B1. 04, Apto. 61. Londrina - PR E-mail: claudianevess@sercomtel.com.br.
} 
Tomás, salientando conceitos que tiveram forte influência na gênese da profissão, como também em artigos escritos por assistentes sociais e colaboradores da Revista Serviço Social - de circulação entre professores do curso de Serviço Social e assistentes sociais no período de 1939 a 1952.

Santo Tomás de Aquino foi um teólogo que viveu no século XIII (1225 - 1274) e seus escritos marcaram profundamente a teologia cristã, ao estabelecer e fundamentar uma colaboração entre filosofia e teologia, entre razão e fé. Dele nos interessa a noção de pessoa humana e seu pensamento quanto às relações entre Igreja e Estado, aspectos que tiveram profundo significado para a formação profissional das primeiras assistentes sociais. Se nos detivermos nos discursos destas assistentes sociais que lecionavam para futuras profissionais, verificaremos que os postulados tomistas estavam presentes em seus discursos e em seu agir profissional.

Os homens eram concebidos como seres criados à imagem e semelhança de Deus, e almejavam felicidade eterna, isto é, Deus. Para o alcance da felicidade, era preciso que corpo e alma estivessem equilibrados, em harmonia, no entanto, fatores externos desviavam a busca dessa felicidade, como o trabalho em excesso, a lascívia, o jogo, a bebida, os bens materiais, o que gerava a desorganização social. Assim, as próprias profissionais justificavam a necessidade de um assistente social junto aos trabalhadores e seus familiares com o objetivo de orientá-los nos aspectos moral e religioso. Uma professora do curso de Serviço Social salientava que a questão social deveria ser encarada como uma crise social das instituições e como uma crise de costumes:

A questão social, entretanto, é fundamentalmente uma questão moral. O trabalho é um ato humano, e como tal, regido pela moral que lhe impõe deveres correspondentes às necessidades da vida. $\mathrm{O}$ capital baseia-se no direito natural e é, portanto, justificado pela moral.[...]. A ordem social só será possível quando se vir no homem uma personalidade natural anterior e superior àquela que a vida em sociedade lhe confere; um ser inteligente e independente que, dotado de uma consciência que lhe dá plena responsabilidade de seus atos, tende para seu fim natural e último Deus (TELLES, 1939, p.3).

Esta concepção fundamentava o agir profissional das assistentes sociais que deveriam conhecer as causas do desajustamento do homem em relação à sociedade e, com base nas leis da Igreja e de Deus, combater a raiz desta não-adaptação. Segundo a oradora da turma de formandas de 1940 da Escola de Serviço Social de São Paulo:

O Serviço Social vai à causa das misérias e dos desajustamentos sociais, buscando os males em suas raízes; por isso mesmo é de ação curativa e preventiva. $\mathrm{O}$ assistido, o deficiente é elemento ativo no seu próprio reajustamento social. O Serviço Social não se limita a um auxílio paliativo, mas agindo sobre o indivíduo e a sociedade visa colocar o necessitado, tanto quanto possível, em condições normais de vida. O Serviço Social informado do amor de Deus e do próximo é em nossos dias a expressão mais alta da caridade cristã (CAMARGO, 1941, p.33).

Mas, que Deus seria este e que Igreja seria esta? Na Europa, o Serviço Social surgiu de ações de membros da Igreja Católica que nesse período, retomou o teólogo Santo Tomás de Aquino para reconquistar seu espaço numa sociedade que passava por profundas transformações.

A importância de Tomás de Aquino consiste em ter encontrado a fórmula adequada para "cristianizar" a obra de Aristóteles, incorporando-a à teologia cristã. Assim sendo, sua obra é considerada o ponto de referência mais alto da Escolástica³ .

As principais partes da obra de Aristóteles foram traduzidas para o latim, pela primeira vez, na segunda metade do século XII, abrindo um novo mundo para

\footnotetext{
${ }^{1}$ De acordo com Costa (1993, p.20), Escolástica é definida como: "A filosofia cristã da Idade Média (séculos IX a XIV) e tem como característica sua dependência em relação à teologia. O termo "Escolástica"designa todo tipo de filosofia elaborada em função de uma religião ou mesmo doutrina filosófica cujos princípios são admitidos sem críticas."
} 
os professores da teologia cristã, até então fortemente influenciados pelas idéias neo-platônicas, assimiladas pelas obras de Santo Agostinho (GARDEIL, 1967). No entanto, os esquemas herdados da razão agostiniana e neoplatônica mostravam-se inadequados para dar uma resposta aos anseios intelectuais do século XIII, que buscavam estabelecer uma relação entre razão e fé, bem como compreender o conteúdo da fé, isto é, da revelação divina, baseada na razão.

Santo Tomás, procurando responder a estes anseios, vai fundamentar-se em Aristóteles para provar a existência de Deus, assim como para justificar o conteúdo da fé. A fé orientaria a razão, assim como a razão comprovaria verdades doutrinais, possibilitando elaborar um discurso de caráter teológico.

É importante salientar que, para ele, o saber teológico não supera o saber filosófico nem a fé substitui a razão: "o homem e o mundo gozam de uma relativa autonomia, sobre a qual deve-se refletir com os instrumentos da razão pura, fazendo frutificar todo o potencial cognoscitivo para responder à vocação original de "conhecer e dominar o mundo" (AMARAL, 1998).

Aristóteles afirma que o homem, por natureza, é um animal social e político, porque não se basta a si mesmo para assegurar a sua sobrevivência, necessitando associar-se aos seus semelhantes para superar as dificuldades encontradas na natureza. É pelo convívio com outros que o homem ira buscar o que lhe falta para construção das condições que lhe permitam exprimir e viver as sua virtudes de ser humano (AMARAL, 1998).

Outro aspecto importante e que nos interessa no momento para compreendermos as ações do Serviço Social diz respeito à comprovação da existência da alma. Para Santo Tomás, alma significa "o princípio da vida, o primeiro princípio vital. A alma é precisamente $\mathrm{o}$ ato do corpo que, feito de matéria, estava em potência para a receber" (GARDEIL, 1967, p.373). Sem ela, o corpo seria imóvel, morto.
A alma possui uma autêntica espiritualidade, pois é "uma substância simples, independente da matéria, capaz de existir e atuar sem ela e por isso de se separar dela" (AMEAL, 1961, p.375). O homem deve a totalidade de seu ser à alma: o existir, a vida, a energia sensitiva, a racionalidade.

A alma não é espírito puro, nem substância completa, visto que seu caráter específico é o de se unir a um corpo. Não é substância completa, porque não pode, por si só, realizar todas as suas operações, como as da vida vegetativa e sensitiva. Portanto, é impossível à alma constituir-se uma pessoa, porque o homem é ser composto, composto de alma e corpo. A união com a matéria não significa para a alma motivo de rebaixamento; ao contrário, é um bem, pois é produto da Vontade Divina. O corpo não é o cárcere da alma, mas seu servidor. Há que se acrescentar que a alma necessita ser atualizada pela matéria, pois "É um ser incompleto, seu grau de autonomia é demasiadamente imperfeito para poder expandir-se independentemente do corpo" (AMEAL, 1961, p.379).

Para Aquino, existem tantas almas quanto o número de corpos, isto é, homens. A divisão da matéria fundamenta a multiplicidade das almas, portanto, das inteligências:

[...] a inteligência é uma parte, uma faculdade da alma, e esta, por sua vez, a forma do corpo. É impossível que haja uma única forma para várias realidades numericamente distintas, como é impossível que essas realidades numericamente distintas tenham um único ser. Pois que o princípio do ser é a forma (AMEAL, 1961, p.380).

Tomás de Aquino assinala que a alma está unida ao corpo como forma, não havendo num mesmo corpo várias almas de essência diversa, alma intelectual, alma vegetativa e alma sensitiva. $\mathrm{O}$ intelecto é a única forma da vida do homem e compreende as funções vegetativas e sensitivas. E essa substância intelectual, incorruptível por natureza, está para o corpo como a forma para a matéria. Todavia, a alma sensitiva é sujeita à corrupção e, por ser apenas sensitiva, pode ser destruída: "Alma 
intelectual contém, pois, na sua perfeição, toda a realidade da alma sensitiva dos animais e da alma vegetativa das plantas" (AMEAL, 1961, p.383).

Santo Tomás declara que a alma encontra-se em cada órgão do corpo, pois a ele está unida como forma. Ela é, portanto, uma forma substancial e constitui não só a perfeição do todo, mas também a de cada parte. A aliança entre alma e corpo ocorre não como problema de união entre duas substâncias que se supõem completas, mas como problema de união entre duas substâncias incompletas, para então, formar um ser composto, completo. O que prevalece e atua é a união de alma e corpo, o homem íntegro, a pessoa.

Deus, origem e fim do homem, forma o corpo humano. Tomás de Aquino não se utiliza do verbo criar, mas formar, pois, segundo ele, subentende-se que já existia a matéria do corpo humano, e somente Deus pode operar a formação. Deus formou o homem e atribuiu-lhe primeiro a virtude de transmitir a outros corpos, homens, sua semelhança. Também a alma origina-se da vontade de Deus, no movimento de sua união com o corpo. O objeto final deste ser composto, corpo e alma, ou melhor dizendo, o homem, é a felicidade. E ela somente é encontrada no Bem, no Bem infinito, ou seja, Deus, porquanto somente no amor divino está a felicidade perfeita. Tendo a alma inspiração divina, também o corpo é perfeito no seu aspecto físico e espiritual.

Ao nos reportarmos ao Serviço Social, verificaremos que a concepção de homem teve profunda repercussão no exercício profissional. Idéias como dignidade da pessoa humana, sociabilidade essencial da pessoa humana, perfectibilidade humana são originárias do tomismo, porque parte do pressuposto do homem como constituído de corpo e alma, filho de Deus, portanto merecedor de respeito e dignidade. Quando estes lhes são negados, cabe ao Serviço Social buscar as causas desta falta de respeito, ou melhor dizendo, deste desajustamento e combatê-lo. Malheiros (1939, p.3), em um artigo afirma que o assistente social é o agente que irá atuar sobre o homem e sobre a sociedade, para tanto:
É necessário pois ao assistente social um preparo especialisado, tendo-se em vista o material com que trabalhará, porquanto, agindo sobre o homem, deverá conhece-lo tal como é em suas partes constitutivas, corpo e espírito. Como reajusta-lo à sociedade si ignorar suas possibilidades e deficiências físicas ou espirituais?

\section{Relação entre Igreja e Estado em Tomás de Aquino}

O homem é um ser social e é por meio da convivência com outros homens que encontrará a felicidade eterna. Mas, para viver em sociedade, é necessária uma ordem que discipline e oriente as ações e comportamento dos homens. E esta virá de uma autoridade, constituída e nomeada por estes mesmos homens. Mas, esta autoridade não está acima da sociedade. Ao contrário, como diz Mancini (1939, p.3):

\begin{abstract}
A autoridade tem, por conseguinte, explicação numa ordem superior, num Ser Supremo. Sob o ponto de vista natural ela não se justifica e serão legítimos, ao contrário, o anarquismo, e sua conseqüência, o despotismo. O governante é um concessionário do poder, que lhe é conferido, mediatamente, pelo Autor da autoridade e, imediatamente, pela eleição dos seus concidadãos...Assim, a autoridade nos deve merecer o máximo respeito sendo lícito que exija de nós, sacrifícios individuais que possibilitem a coexistência social.
\end{abstract}

Em sua filosofia política, Santo Tomás de Aquino trata das relações de poder, cujo ponto inicial repousa na afirmação de que o homem é um ser por natureza social e, assim, procura o convívio e a cooperação social de outros semelhantes para a busca das condições necessárias à plena realização de suas virtualidades de ser humano. Eesta convivência social exige o político, ou seja, um poder que oriente e organize este convívio. Em todas as unidades ou grupos, desde a família até o Estado, impõe-se a organização política como exigência natural para realização humana. 
Este poder nada tem de arbitrário ou autoritário, é um instrumento utilizado pela natureza para alcançar e legitimar a autoconstrução e o aperfeiçoamento do homem. Deve alcançar e garantir o bem comum, como podemos verificar no texto extraído de Santo Tomás: "Cabe ao rei, na promoção do bem comum, ser solícito com o desenvolvimento do povo; e para isto tem de cumprir todo o anterior e corrigir o que estiver mal, suprir o que faltar, e procurar aperfeiçoar aquilo que puder ficar melhor" (AQUINO apud AMARAL, 1998, p.121)

Tomás de Aquino afirma que há uma lei que governa todo o universo, todas as atitudes do homem e da natureza, conhecida como lei eterna, porque concebida por Deus, e pela qual Deus administra todas as coisas para determinado fim, conhecida apenas por ele e pelos bem-aventurados. Dessa lei origina-se a lei natural, que está presente em cada homem. De acordo com Reale e Antiseri (1990, p.567):

Para o homem, como para todo ente, a sua própria conservação é um bem. Para o homem, como para todo animal, é bem seguir os ensinamentos universais da natureza: união do macho e da fêmea, proteção e crescimento dos filhotes, etc. Para o homem, enquanto ser racional, é bem conhecer a verdade, viver em sociedade.

Intimamente ligada à lei natural está a lei humana, ou seja, a lei jurídica, elaborada pelos homens para evitar que os indivíduos cometam o mal em detrimento do bem. Para Reale e Antiseri (1990, p.568): “A lei humana é a ordem promulgada pela coletividade, ou por quem tem a responsabilidade pela comunidade, tendo em vista o bem comum."

Cabe a cada um e, mais especificamente, à pessoa pública, cuidare exigir o cumprimento desta lei. A união de vários homens buscando o bem comum, a felicidade da coletividade, dá origem ao Estado, que nada mais é do que uma sociedade perfeita, porque é a união de homens buscando o bem comum, e porque tem como objetivo final o bem comum. O Estado, para Santo Tomás, é uma necessidade que deriva da natureza do homem, o qual:
Pode encaminhar os homens para o bem comum e pode favorecer algumas virtudes, mas não permite ao homem alcançar o seu fim último, que é sobrenatural. Em suma, a lei natural e as leis positivas servem aos fins terrenos do homem. Mas, o homem tem um fim sobrenatural, que é precisamente a bem-aventurança eterna" (REALE; ANTISERI, 1990, p.570).

Na perspectiva tomista, o poder temporal é complementar ao poder espiritual, permitindo que este propicie àquele alcançar sua finalidade, ou seja, a felicidade eterna. Dessa forma, justifica-se a intervenção do poder espiritual quando o poder temporal não garante $\mathrm{o}$ alcance desta finalidade. $\mathrm{O}$ poder temporal, afirma Amaral (1998, p.130): "Admite intervenções por parte do poder espiritual superior, sempre que dificultar ou não produzir as condições apropriadas para que este execute a sua missão de assegurar para o homem a finalidade transcendental que lhe foi incutida pelo Criador".

Sendo o Estado uma sociedade perfeita, goza de autonomia. No entanto, como a Igreja tem por objetivo final o bem sobrenatural, esta é superior àquele, pois goza de maior perfeição, cabendo ao Estado subordinar-se, no que concerne ao fim sobrenatural do homem, à Igreja, visto que esta última é dotada de meios para aperfeiçoar o Estado. Como nos diz Costa (1993, p.73): “Assim como a razão humana está naturalmente subordinada à razão divina, a filosofia à teologia e a ciência à fé, o Estado deve estar subordinado à Igreja, pois esta encarna os interesses eternos e superiores do homem."

No entanto, é importante frisar que Santo Tomás afirma que esta subordinação somente ocorrerá quando o interesse temporal tiver relação direta com o divino e eterno, cabendo à Igreja a orientação final e decisiva.

No que se refere ao Serviço Social, deveriam seus profissionais contribuir para busca de uma convivência harmoniosa entre todos na sociedade. Em um discurso proferido pelo orador Luiz Carlos Mancini, em março de 1940, por ocasião da formatura da turma de assistentes sociais de 1939 da Escola de 
Serviço Social de São Paulo, observamos esta preocupação quando este abordou a situação política e moral da época e o sentido do serviço social em uma sociedade "convulsionada por profundas desordens de estrutura e de mentalidade":

Para o advento do Corporativismo, preconizado pela Constituição Federal, não basta uma legislação social abundante. A legislação não age por si. Os textos de lei não operam prodígios. Ademais, muita vez, a lei não encontra ambiente para sua expansão e nem tão pouco as alterações estruturais e de mentalidade que tornam possível, eficaz e fácil, a sua aplicação. É necessária a coadjuvação do Serviço Social para promover a adaptação do meio à legislação e insuflar no indivíduo o espírito da lei (MANCINI, 1940, p.6).

Para o Serviço Social, nesse momento, o homem buscaria na sociedade as condições necessárias para sua subsistência e aperfeiçoamento, visto que a sociedade deve conter abundância de bens para o corpo e para a alma. Daí o Estado intervir em ações que garantiriam a edificação de uma sociedade em bases cristãs.

\section{A Doutrina Social da Igreja e o Serviço Social}

Com a decadência da civilização medieval, em fins do século XV e com a gestação da sociedade moderna, a noção de pessoa vai assumindo novas feições: o homem não tem em vista, exclusivamente, a felicidade da vida eterna, mas orienta-se para uma felicidade terrena. Ao mesmo tempo, as relações entre Igreja e Estado vão-se definindo para uma completa separação, isto é, separação entre poder temporal e espiritual.

No que diz respeito a essa separação, verificaremos que, em alguns países da Europa, como França, Bélgica, Alemanha, ela já estava completa no século XIX, o que exigiu da Santa Sé ações e medidas que revertessem esse quadro. Com efeito, a influência da Igreja Católica junto às classes trabalhadoras e burguesa diminuiu dramaticamente, ao passo que junto a esses segmentos cresceu, respectivamente, a influência do socialismo e do liberalismo.
A retomada do tomismo pela Igreja Católica remonta ao século XVIII; porém, foi o Papa Leão XIII, com a encíclica Aeterni Patris, em 1879, que deu início ao movimento neotomista e neo-escolástico (CAMPOS, 1966, p.35).

Na Encíclica Rerum Novarum, Leão XIII codifica a Doutrina Social da Igreja e estabelece as normas que os patrões e os trabalhadores deveriam seguir nos aspectos moral e material. Para tanto, o Pontífice novamente busca na obra teológica de Tomás de Aquino fundamentos para a concepção de lei, justiça, Estado, autoridade e política.

A alta hierarquia da Igreja estimulou a criação de diversos institutos, publicações e universidades pela Europa para divulgação do tomismo, declarando-o patrono das escolas católicas. No dizer de Campos (1966, p.36): "Esta orientação, em direção à unidade, acentua-se ainda mais, com os sucessores de Leão XIII: Pio X e Bento XV, segundo o qual a Igreja havia proclamado a filosofia de Santo Tomás como sua própria doutrina e, finalmente, com Pio XII."

O Brasil não ficou imune às idéias tomistas. Este movimento se fez presente desde a época da colonização, quando os padres da Companhia de Jesus, em seus colégios, ministravam aulas de filosofia e teologia. No entanto, com a expulsão dos jesuítas do Reino Português (1759) e de suas colônias, entre as quais, o Brasil, o ensino da filosofia tomista foi deixado de lado, dando lugar às idéias iluministas.

Este afastamento das idéias tomistas perdurou até o século XX, quando, com a fundação da primeira universidade católica, a Pontifícia Universidade Católica, no Rio de Janeiro, pelo padre Leonel Franca deu-se uma grande expansão e notável evolução do tomismo no Brasil. Enfim, o reviver do tomismo foi possível pela ação das universidades católicas espalhadas pelo país e publicações de cunho religioso e filosófico, do Centro Dom Vital, que congregava intelectuais católicos no período, bem como de pensadores importantes, como Maurício Teixeira Leite Penido, Leonardo Van Acker, Henrique Cláudio de Lima Vaz. 
A presença das idéias tomistas repercutiu profundamente na percepção que a Igreja tem acerca da realidade social, política e econômica, servindo como grande escudo contra as idéias anarquistas e comunistas que se espalhavam entre os trabalhadores seja da Europa, seja do Brasil.

O padre Roberto Sabóia de Medeiros (1943) em artigo para Revista Serviço Social afirmava que em todas as coisas e em todos os planos haveria aspectos terrenos e espirituais e a Igreja Católica, por sua natureza, social e universal, teria por missão infundir $\mathrm{o}$ amor e a caridade em todos os homens. Amor que, segundo esse prelado, se mal empregado, poderia conduzir a perversões e injustiças:

Que tem que ver a Igreja com o social? Se a nossa interpretação é exata e se no Novo Testamento só há uma lei, a caridade (Rom, 13), a Igreja é a autêntica missionária do social, a que deve diretamente tratar do social. Da salvação do amor, da retidão do amor, da condução e da polarização do amor, das concretizações e encarnações do amor. Que em todas as coisas mais terrestres, um sindicato, ou uma sociedade anônima, seja adotada uma fórmula tal que o amor vá ao verdadeiro bem" (MEDEIROS, 1943, p.14).

Por este motivo, a Igreja deveria dedicar-se também aos problemas sociais, difundindo na sociedade os princípios católicos e cristãos, os quais levariam à construção de uma ordem social cristã, promovendo, dessa forma, o bem autêntico, isto é, a "Verdade de Cristo" (MEDEIROS, 1943, p.17).

A Igreja, na figura do Papa, bispos, padres e religiosas, intervém, desde o século XIX, de forma clara e definida na área social, sob a alegação de estar realizando sua principal missão, ou seja, levar os homens a cumprirem a tarefa de dar glória a Deus, bem como difundir a caridade.

O pontificado do Papa Leão XIII (1878 - 1903) foi marcado pela atenção dada à questão social, pois, percebendo o crescimento das idéias socialistas, anarquistas e anticlericais entre o movimento operário, com a progressiva diminuição do poder de influência da Igreja entre a classe trabalhadora, o Papa voltou suas atenções para esta situação, por meio de cartas, sermões e pela publicação, em 1891, da primeira encíclica social, a Rerum Novarum. O principal objetivo desse documento papal era salientar a exploração do trabalhador pelo detentor dos meios de produção, motivo pelo qual ele sugeriu a união entre as classes para minorar esta situação. É o que se pode observar em um trecho extraído da encíclica papal:

Em todo o caso, estamos persuadidos, e todos concordam nisto, de que é necessário, com medidas prontas e eficazes, vir em auxílio dos homens das classes inferiores, atendendo a que eles estão, pela maior parte, numa situação de infortúnio e de miséria imerecida. O século passado destruiu, sem as substituir por coisa alguma, as corporações antigas, que eram para eles uma proteção; os princípios e o sentimento religioso desapareceram das leis e das instituições públicas, e assim, pouco a pouco, os trabalhadores, isolados e sem defesa, tem-se visto, com o decorrer do tempo, entregues ã mercê de senhores desumanos e à cobiça duma concorrência desenfreada (LEÃO XIII, 1965, p.10).

Não obstante, no Brasil a preocupação da Igreja Católica, de acordo com Bruneau (1974), era reconquistar os privilégios perdidos com a Proclamação da República, em 1889. O governo provisório, com o Decreto de 1890, promovia definitivamente a separação entre Igreja e Estado, permitindo o fim do Padroado e o nascimento de um Estado Republicano laico. Como resposta a este Decreto, 12 bispos do Brasil, através da Carta Pastoral Coletiva do Episcopado Brasileiro salientavam:

Que será de ti, coitado e querido povo do Brasil; se além de tudo te roubam também a tua fé, e ficas sem Deus, sem Deus na família, sem Deus na escola, sem Deus no governo e nas repartições públicas, sem Deus nos últimos momentos da vida, e até na morte e na sepultura sem Deus! Será possível !

Basta, que te não há de suceder tamanha desgraça! Povo católico, tu ouvirás a voz de teus pastores, que só se inspiram no vivo desejo de salvar-te. 
E primeiramente, que se há de pensar dessa separação da Igreja e do Estado, que infelizmente está consumada entre nós pelo decreto do governo provisório de 7 de janeiro do corrente ano? É porventura, em si, boa, e deve ser aceita e aplaudida por nós católicos?

Em segundo lugar, que havemos de pensar do decreto enquanto franqueia liberdade a todos os cultos?

Em terceiro lugar, enfim, que temos de fazer os católicos do Brasil em face da nova situação criada a nossa igreja?" (RODRIGUES, 1981, p.19).

Diante da resposta imediata e veemente da hierarquia, membros do governo provisório, na elaboração da primeira Constituição Republicana, concordaram por reinterpretar alguns dos artigos do referido decreto. Mas, na Constituição, outorgada em 1891, alguns itens permaneceram, como a liberdade de crença e de culto, a obrigatoriedade do casamento civil, o ensino laico nas escolas públicas, a secularização dos cemitérios, a inelegibilidade de membros do clero para cargos no Congresso.

Em 1916, D. Sebastião Leme, em sua posse como arcebispo metropolitano de Olinda, redigiu uma Carta Pastoral dirigida aos seus diocesanos, na qual combatia a perda de poder e espaço pela Igreja no cenário nacional e lançou as bases para um programa de reivindicações que deveriam ser alcançadas pela mobilização dos católicos, como se pode ler no seguinte trecho da Carta:

Na verdade, os católicos, somos a maioria do Brasil e, no entanto, católicos não são os princípios e os órgãos de nossa vida política. Não é católica a Lei que nos rege. Da nossa fé prescindem os depositários da Autoridade.

Leigas são as nossas escolas, leigo o Ensino. Na força armada da República, não se cuida da religião.

Enfim, na engrenagem do Brasil oficial não vemos uma só manifestação de vida católica [...]

É evidente, pois, que, apesar de sermos a maioria absoluta do Brasil, como Nação, não temos e não vivemos vida católica.
Quer dizer: somos uma maioria que não cumpre os seus deveres sociais.

Obliterados em nossa consciência os deveres religiosos e sociais, chegamos ao absurdo máximo de formarmos uma grande força nacional, mas uma força que não atua, e não influi, uma força inerte.

Somos, pois, uma maioria ineficiente. Eis o grande mal" (RAJA GABAGLIA, 1962, p.67-68).

D. Leme tornou-se figura de destaque na direção da Igreja, tendo sido nomeado cardeal-arcebispo do Rio de Janeiro em 1930 (até 1942), mobilizou e restaurou antigos privilégios, a partir da reconciliação da Igreja com o Estado. A preocupação dominante das autoridades eclesiásticas, durante as três primeiras décadas do século $\mathrm{XX}$, foi a busca da confirmação da Igreja Católica como detentora de um poder espiritual que colaborasse com o Estado na manutenção da ordem estabelecida. Afirma Azzi (1981, p.5):

\begin{abstract}
A palavra "restauração" passa a ser utilizada pelos bispos brasileiros como eco do lema do pontificado de Pio XI (1922-1939): "restaurar todas as coisas em Cristo". Em outras palavras, restaurar no mundo o domínio espiritual da fé católica. Existe portanto uma sintonia muito grande entre as metas propugnadas pelos prelados brasileiros e a orientação básica da Santa Sé. Os bispos do Brasil atuam em plena consonância com o Pontífice Romano.
\end{abstract}

Com a Constituição de 1934, algumas exigências da Igreja foram garantidas, graças à intensa campanha envolvendo leigos e organizações católicas, assim como grandes mobilizações de massa, como a entronização de Nossa Senhora Aparecida, proclamada pelo Papa como padroeira do Brasil, a inauguração do Cristo Redentor no Corcovado, em 1931, quando, no dizer de Della Cava (1975, p.15):

[...] foi a ocasião em que Leme, cercado de 50 arcebispos, bispos e uma multidão confusa, 'estipulou o preço' do apoio da Igreja. Num discurso que um regime mais autoritário teria censurado como 'subversivo', Leme advertiu insolentemente: 'ou o Estado...reconhece o Deus do povo ou o povo não reconhecerá o Estado. 
Assim sendo, para que a retomada do poder espiritual e temporal se efetivasse, diversas instituições religiosas foram chamadas para este fim, como as paróquias, as escolas religiosas, a imprensa católica. Também o movimento laico foi convocado a dar sua contribuição, principalmente com o surgimento das seguintes associações e institutos religiosos: Ação Universitária Católica, Instituto de Estudos Superiores (futura Universidade Católica), Associação de Bibliotecas Católicas, Círculos Operários, Liga Eleitoral Católica a Ação Católica Brasileira (IAMAMOTO; CARVALHO, 1990).

Além das associações religiosas, a hierarquia católica considerava também necessário incentivar a fundação de instituições que atendessem aos trabalhadores, os quais viviam uma crescente pauperização, com a falta de emprego, moradia, saúde, educação, a despeito do desenvolvimento econômico brasileiro. Assim, com o objetivo de minorar a pobreza e restabelecer a ordem social, econômica e política, também foram criadas a Associação das Senhoras Brasileiras (1920), no Rio de Janeiro, e a Liga das Senhoras Católicas (1923), em São Paulo.

Essas ações da Igreja poderiam conduzir a avaliação de que a atuação desta instituição religiosa no combate à pobreza era motivada simplesmente pela necessidade de recuperar o prestígio perdido, $o$ que não deixa de ser correto. No entanto, essa preocupação com a questão social também poderia ser explicada pelo crescimento do movimento operário no Brasil, com a vitória da Revolução Russa, em 1917, com a divulgação das idéias socialistas entre os trabalhadores e com a fundação do Partido Comunista no Brasil, em 1922.

Podemos comprovar esta afirmação no discurso do Arcebispo Metropolitano de São Paulo, Dom José Gaspar de Afonseca e Silva, por ocasião da formatura dos assistentes sociais, em 9 de março de 1940:

O mundo assiste neste momento, ao fracasso da política materialista, e também nós somos vítimas nesta horrenda tragédia. Deus foi proscrito das leis, dos tribunais e das escolas, e quem assim desterrou pensava construir outro mundo melhor, mundo esse que se retrata nas páginas diárias dos nossos jornais, onde vemos o derrocar de todas as sonhadas grandezas sem Deus, a brutalidade com que o materialismo costuma tratar as consciências, a triste safra da semente má que semeou nas escolas, os frutos pêcos dos princípios com que pretende educar as inteligências (SILVA, 1940, p.2)

Quanto ao Estado, Iamamoto e Carvalho (1990) afirmam que, na Primeira República, este optou por duas medidas para atacar a questão social: a repressão policial para impedir greves, dispersar manifestações operárias; e a formulação de algumas leis trabalhistas, como a regulamentação da jornada de trabalho, do trabalho do menor, da mulher, férias, caixa de seguro, sindicatos e lei de acidentes de trabalho, em resposta às pressões do movimento operário e como forma de manter o controle social e político.

Com a Revolução de 30 e ascensão de Getúlio Vargas ao poder, houve uma ampliação desta legislação, bem como maior atenção à área assistencial. Para isso, o Estado convocou a Igreja, que já vinha exercendo, de forma sistematizada, este tipo de trabalho junto à população carente desde o período anterior ao Império, como os serviços hospitalares e assistenciais. Esta convocação fundamentava-se tanto na experiência da Igreja nesta área como na contribuição desta na manutenção da ordem, a partir de um discurso paternalista e autoritário, o qual visava harmonizar as classes sociais em conflito, não questionando a ordem social estabelecida (IAMAMOTO; CARVALHO, 1990).

A Igreja discordava do governo Getúlio Vargas, que lhe proporcionava pouca participação nas esferas de decisão, mas não questionava a autoridade do Presidente perante a população. Na verdade, havia uma clara exortação de respeito à autoridade constituída, legitimando a autoridade, visto que a convivência social exigia um ordenamento político, o qual teve por finalidade última o bem comum: 
A lei visa primeiramente, e a título de princípio, a ordem com vista ao bem comum. Ordenar qualquer coisa para o bem comum pertence ao povo no seu conjunto ou a alguém que represente o povo. É por essa razão que o poder legislativo pertence a todo o povo, ou então a uma personalidade oficial que tem o povo ao seu cuidado (AQUINO apud AMARAL, 1998, p.124-125)

Como consequiência, também havia no Serviço Social uma exortação quanto à importância em respeitar a autoridade, bem como a necessidade de o Estado buscar o bem comum. Mancini (1939, p.3) salienta o valor da autoridade em seu artigo:

O Estado pode e deve cobrar impostos e mesmo regular o exercício dos direitos naturais de acordo com a regra: procurar o máximo de segurança com o mínimo de entraves, em vista do bem comum. Este será sempre o princípio condicionador. Para tê-lo sempre em mira, nítido e exato, o Estado se deve abeberar nas diretrizes fundamentais que o Poder Espiritual - primeira sociedade - prescreve.

Para a Igreja, o mais importante neste momento era a idéia de que a causa principal do desequilíbrio harmonioso da sociedade era o desprezo e esquecimento do fim sobrenatural: a busca do bem comum, isto é, a felicidade eterna.

\section{Serviço Social}

O Serviço Social surge, neste momento histórico, fundamentado em incentivos de frações da classe dominante, tendo a Igreja Católica como a grande fomentadora desta nova atividade que iria atuar junto aos pobres. $\mathrm{O}$ discurso que fundamentava esta ação era claro, isto é, a necessidade em evitar possíveis influências, entre os trabalhadores, de "lideranças daninhas".

Requeria-se um profissional que atendesse as exigências de uma nova ordem econômica, contribuindo para a ascensão da burguesia industrial ao cenário político e econômico, a qual não poderia sofrer interrupções com questões dos trabalhadores. Como bem esclarece Maria Kiehl, assistente técnica do Departamento de Serviço Social e professora do curso de Serviço Social de São Paulo:
O assistente social tem, pois, de zelar pelos interesses dos operários proporcionando-lhes um ambiente de trabalho onde as regras da moral e da higiene são respeitadas, onde por uma judiciosa distribuição dos cargos consegue para o operário uma justa retribuição para o seu trabalho. Por outro lado, zela pelos interesses do patrão formando a consciência profissional do operário, fazendo-o compreender a necessidade de ter cuidado com o maquinismo, com a matéria-prima, desenvolvendo uma ação apaziguadora afim de manter o bom espírito, a regularidade do trabalho. Evitar acidentes, trabalhos mal feitos, desperdícios, greves, instabilidade da mão-de-obra, é servir de maneira muito apreciável, os interesses financeiros da empresa (KIEHL, 1939, p.8).

Ademais, o Serviço Social nasceu em um momento em que a Igreja fomentava a criação de diversos movimentos, cujo objetivo era disciplinar e coordenar o apostolado laico, bem como divulgar sua doutrina social, através da Ação Católica, Juventude Estudantil Católica, Juventude Operária Católica, Juventude Universitária Católica e outras.

Com apoio do Centro de Estudos e Ação Social, criado em 1932, e dos diversos cursos por ele promovidos para as senhoras católicas, foi fundada em 1936, em São Paulo, a primeira escola de Serviço Social do Brasil, com o objetivo de oferecer, às pessoas interessadas em ajudar aos pobres, preparo para tal tarefa. As exigências para se tornar assistente social eram claras:

Para a atividade que deve desempenhar um trabalhador social, exige-se-lhe uma formação de consciência. Mais: elevação interior, dedicação excepcional com que abafará o egoísmo que cada um traz dentro de si. Ainda: uma decidida vontade de servir desinteressadamente (no sentido de vaidade, de publicidade) e anonimamente (com modéstia) a sociedade. Em suma, o Serviço Social reclama uma verdadeira vocação de seus agentes (FERREIRA, 1939, p.4).

No entanto, por meio da leitura de artigos do período em questão, verificamos que não bastava mais apenas a boa vontade das católicas em atender a crescente população pobre das cidades. Qualificar pessoas para estes atendimentos tornava-se um dos 
principais motivos para fundação da escola de Serviço Social, como podemos observar do texto extraído de artigo de Malheiros (1939, p.3): "Se, com reta intenção, damos uma esmola a um pedinte, estamos fazendo caridade, porém, não Serviço Social, porque se quisermos fazê-lo devemos procurar conhecer como o pedinte chegou a essa situação, quais os fatores que intervieram, quais as causas."

Para matricular-se no curso regular, também era necessário atender algumas exigências burocráticas, conforme registrado por ocasião da fundação do Instituto de Serviço Social em São Paulo:

a) apresentar prova de idade mínima de 18 anos, b) atestado de sanidade, c) atestado de idoneidade passado por um sacerdote, d) comprovar ter feito curso secundário ou preparo equivalente, e) ser considerado habilitado nos exames de seleção do Curso Intensivo (INSTITUTO de Serviço Social, 1940, p.8).

Como era de se esperar, a visão de homem e mundo das primeiras assistentes sociais fundamentava-se na filosofia e teologia da Igreja Católica, mais especificamente da doutrina social da Igreja. Na formação profissional destas assistentes sociais, a presença da doutrina social era o fundamento teórico-metodológico daqueles que ministravam aulas para as primeiras alunas do Serviço Social, bem como do projeto de formação profissional. Ratificamos esta afirmação valendo-nos do artigo da diretora da Escola de Serviço Social de São Paulo, Helena Iracy Junqueira (1943, p.46):

O Serviço Social supõe uma filosofia de vida [...]. Filosofia de vida supõe necessariamente uma concepção religiosa. Donde, impossível Serviço Social neutro.

Segue-se portanto, a necessidade da formação doutrinária. Esta formação não terá propriamente um lugar à parte na organização dos programas a não ser os Cursos de Religião. Mas ela entrará, a cada momento, na maneira de considerar o Homem, os seus problemas, as suas soluções [...]
Segue-se ser indispensável a mesma orientação doutrinária entre os professores, e um ambiente onde se respire essa mesma doutrina para que ela possa impregnar a personalidade do futuro assistente social."

Outros professores também salientavam a importância da doutrina social da Igreja na formação profissional. De acordo com Urbina Telles, o Serviço Social não poderia se limitar a uma técnica. Por lidar com seres humanos, necessitaria de características singulares, pois o homem é movido por uma idéia orientadora, a felicidade eterna, exigindo que o assistente social, ao lidar com este homem, tivesse uma doutrina social que esclarecesse suas ações e que deveria estar presente no ensino teórico e prático. Mas, qual doutrina?

A que envolva o homem em sua verdadeira natureza, atendendo à sua finalidade. A que mostre o homem tal como a razão nôla apresenta: corpo e alma, com um fim supra-terreno. Ser social incompleto utilizando-se da sociedade para atingir seu fim último. Doutrina que não se confunda nem com o individualismo, nem com o coletivismo, mas que fique no meio termo, considerando a eminente dignidade da pessoa humana e a necessidade da sociedade para seu desenvolvimento [...] Uma só doutrina, com princípios que são imutáveis porque perfeitos, encontraremos - Católica (TELLES, 1940, p.4)

A presença da doutrina social católica orientava e fundamentava a leitura que os assistentes sociais faziam acerca da realidade social e econômica brasileira. No discurso de Cecília Camargo, oradora da turma de assistentes sociais de São Paulo, em 1940, observamos essa análise:

Atrás das questões de ordem econômica, social e política há sempre um problema moral. E esse hoje parece foi esquecido. As desordens atuais são conseqüências de fatores morais; o erro foi a expulsão de Cristo da vida social. Abalou-se o fundamento da justiça e da ordem, da moralidade e da pás. Fazem-se leis e tratados, mudam-se os governadores; pretendem os homens construir uma nova pás e uma nova ordem sem Aquele alicerce de toda ordem e de toda pás (sic) (CAMARGO, 1941, p.30). 
A base da ação do assistente social, segundo Urbina Telles, é a justiça e a caridade. A primeira permite ao assistente social compreender o que a sociedade reclama. A segunda permite a ele viver a justiça, dedicando-se ao irmão.

Por conseguinte, há um grande destaque para a importância de o homem ser respeitado em sua integridade, porque ele é o fim último do Serviço Social, o homem em sua totalidade, física e moral, biológica e psicológica, corpo e alma. Porque o homem é fruto e expressão da vontade de Deus, ser supremo e perfeito. Sendo a plenitude do ser humano composta de corpo e alma, é preciso que esta pessoa humana seja respeitada e amada (Santo Tomás).

Como afirma Santo Tomás, apesar de ser o homem um ser completo, ele também necessita de outros para sobreviver, porque é de sua natureza a sociabilidade: "a condição social e política acompanha o homem, desde o estado de inocência, desde o Paraíso" (AMARAL, 1998, p.101). O homem somente consegue se realizar plenamente, quando em convívio com seus semelhantes. Camargo (1941, p.31) em seu discurso de oradora da turma de Serviço Social de 1940 destacou:

É o homem um ser social. Nascendo numa sociedade nela deve desenvolver-se e aperfeiçoarse; nela deve receber um mínimo necessário à vida; a sociedade deve proporcionar-lhe aquele mínimo de bem estar exigido pela dignidade da sua natureza humana. Esse direito a uma existência digna é meio necessário a um fim obrigatório.

Ora, a sociabilidade do homem exige relações humanas que, por sua vez, exige um poder para regulamentá-la, para orientá-la. É por meio do Estado e das leis sociais que se garante $o$ alcance do bem comum, pois, de acordo com Tomás de Aquino, o Estado é uma exigência da natureza humana e as leis sociais são indispensáveis à busca da felicidade relativa e temporal, possibilitando a convivência pacífica e o atendimento das necessidades materiais de todos:

O fim último do político não é substituir-se ao homem, ou ao social, absorvendo-os e desintegrando-os na majestade do seu pretenso poder soberano, mas assegurar que cada homem e cada comunidade possam 'viver segundo a virtude' peculiar da condição e da finalidade que lhes é específica (AMARAL, 1998, p.120).

E o Serviço Social também demonstrou esta preocupação com a autoridade e a necessidade de respeitá-la, assim como de a autoridade respeitar o ser humano. Salientamos um trecho do artigo de Mancini (1939, p.3) para Revista Serviço Social, no qual ele frisa a importância de um poder que coordene as atividades individuais: "a autoridade nos deve merecer o máximo respeito sendo lícito que exija de nós, sacrifícios individuais que possibilitem a coexistência social."

Por último, queremos salientar que também houve, desde o surgimento da primeira escola, uma preocupação com a técnica, fundamentada, não no voluntarismo, mas em um corpo teórico que possibilitasse uma formação profissional eficiente. $\mathrm{O}$ assistente social deveria ter um preparo técnico e uma formação moral sólida, visto que buscaria soluções viáveis para uma harmonia social. Ferreira (1941, p.14), em conferência realizada em São Paulo em 1941, diz:

Visa a Escola a formação de assistentes sociais, dissemo-lo há pouco. Dar, em primeiro lugar, a seus alunos o conhecimento dos problemas sociais; ensinar a técnica apropriada ao exercício do serviço social; finalmente, despertar uma compreensão da grande e urgente necessidade de uma coordenação de esforços, de uma profunda e intensa cooperação social de que os assistentes sociais devem ser vanguardistas. Mas, si este é seu objetivo imediato, outras finalidades deve ela alcançar. Não se funda uma escola unicamente para expedir diplomas, mas antes atuar sobre o meio social e modificar mentalidades, criando um ambiente propício ao pleno desenvolvimento das atividades que seus alunos virão a exercer.

Como podemos apreender do exposto, os alunos de Serviço Social deveriam estudar tudo o que fosse relacionado ao homem e à sociedade para que, respaldados por um preparo técnico adequado e norteado sempre pela caridade, pudessem 
desempenhar um trabalho de reajustadores e orientadores de homens, mulheres, crianças e adolescentes na sociedade a qual, por sua vez, também deveria reajustar-se a estes. O que raras vezes aconteceu, em vista da realidade que se nos apresenta.

\section{Considerações Finais}

Desde o surgimento da profissão, houve uma preocupação com o aporte teórico e técnico que fundamentaria as ações das assistentes sociais. E, em diversos artigos da Revista Serviço Social, pudemos verificar que este corpo teórico foi buscado na doutrina social da Igreja, cuja visão de homem e mundo influenciou decisivamente a nossa profissão.

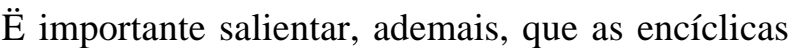
sociais tiveram papel relevante na concepção de mundo de diferentes profissionais e intelectuais em diversas regiões do mundo ocidental cristão, em vista da importância política, cultural e social desta instituição religiosa no período em questão.

E a Igreja Católica, tendo buscado em Santo Tomás de Aquino o caráter teológico e filosófico para justificar suas idéias e ações e sendo a responsável direta pela fundação de várias escolas de Serviço Social no Brasil, possibilitou que na sistematização teórico-metodológica das atividades desempenhadas pelas primeiras assistentes sociais os postulados tomistas se fizessem notar no seu discurso e no seu exercício.

E esta presença, mesmo que de forma não explícita, se fez notar até a década de 60 , quando novas correntes sociológicas passaram a exercer influência no interior da profissão, propondo novas concepções de homem e de mundo.

\section{Referência}

AMEAL, João. São Tomás de Aquino. 5.ed. Porto: Livraria Tavares Martins, 1961.

AMARAL, C. E. P. Subsidiariedade e autonomia em São Tomás de Aquino: uma filosofia política para os nossos tempos. Arquipélago - Ciências Sociais, Açores, n.11/ 12, p.99-131, 1998

AZZI, R. Presença da igreja Católica na sociedade brasileira. Cadernos do ISER, Rio de Janeiro, n.13, p.5-20. 1981.

BRUNEAU, T. O catolicismo brasileiro em época de transição. São Paulo: Loyola, 1974.

CAMARGO, C. Discurso. Revista Serviço Social, São Paulo, n.26, p.30-34, 1941.

CAMPOS, P. N. A Doutrina Social da Igreja: à luz do Vaticano II. Rio de Janeiro: Paulinas, 1966.

COSTA, José Silveira da. Tomás de Aquino: a razão a serviço da fé. São Paulo: Moderna, 1993.

DELLA CAVA, R. Igreja e Estado no Brasil do século XX: sete monografias recentes sobre o catolicismo brasileiro, 1916 - 1964. Estudo CEBRAP, São Paulo, n.12, p.5-52, 1975.

FERREIRA, E. P. Serviço social - serviço de apóstolo. Revista Serviço Social, São Paulo, n.1, p.6-7, 1939.

FERREIRA, F.P. O Serviço Social em São Paulo. Revista Serviço Social, São Paulo, n.28, p. 12-19, 1941.

GARDEIL, H. D. Iniciação à filosofia de São Tomás de Aquino. São Paulo: Duas Cidades, 1967.

IAMAMOTO, M.; CARVALHO, R. Relações sociais e serviço social no Brasil: esboço de uma interpretação histórico-metodológica. 7.ed. São Paulo: Cortez, 1990.

INSTITUTO de Serviço Social. Revista Serviço Social, São Paulo, n.14, p.8, 1940.

JUNQUEIRA, H. I. Considerações sobre organização do programa para escola de Serviço Social. Revista Serviço Social, São Paulo, ano 2, n.31, p.39-48, 1943.

KIEHL, M. A Escola de Serviço Social e os problemas do trabalho. Revista Serviço Social, São Paulo, ano 1, n.1, p.8, 1939 .

LEÃO XIII. Rerum Novarum: carta encíclica de sua santidade o Papa Leão XIII sobre a condição dos operários. 8.ed. São Paulo: Ed Paulinas, 1965.

MALHEIROS, U. O assistente social deve ser um técnico. Revista Serviço Social, São Paulo, ano 1, n.1, p.3, 1939.

MANCINI, L. C. O governo e a autoridade. Revista Serviço Social, São Paulo, ano 1, n.2, p.3, 1939.

MANCINI, L. C. O sentido do serviço social. Revista Serviço Social, São Paulo, ano 1, n.14, p. 6-8, 1940.

MEDEIROS, R. S. Apostolado e realidade social. Revista Serviço Social, São Paulo, ano 2, n.31, p.5-19, 1943. 
RAJA GABAGLIA, L. P. O cardeal Leme $(1882$ - 1942). Rio de Janeiro: José Olympio, 1962.

REALE, G.; ANTISERI, D. História da Filosofia: Antigüidade e Idade Média. 5.ed. São Paulo: Paulus, 1990. v.1. (Coleção Filosofia).

RODRIGUES, A. M. M. A Igreja na República. Brasília: Ed. Universidade de Brasília, 1981.
SILVA, J.G.A. Discurso de paraninfo. Revista Serviço Social, São Paulo, ano 2, n.14, p.2, 1940.

TELLES, G. U. Formação moral do assistente social. Revista Serviço Social, São Paulo, ano 2, n.13, p.4-6, 1940.

TELLES, G. U. Ordem social. Revista Serviço Social, São Paulo, ano1, n.1, p.2-3, 1939. 